\section{Reflections on Contrasting Views on Themes in Chinese Civilization}

\section{Gunnar Haaland}

\begin{abstract}
Like any complex civilization, China contains the confluence of range of traditions of knowledge that people draw on in their interpretations of and reactions to events in the 'world' they are exposed to. However traditions of knowledge serve multiple purposes and may lead to contradictory views on important issues. Chairman Mao when reflecting on two dominant cultural traditions - the Confucian school and the Legalist school - stated that in China there is always two opposite viewpoints. The traditions of knowledge expressing such divergent viewpoints had for more than 2000 years been nurtured and elaborated in the organizational context of the Chinese Empire. An important concern in these traditions is their emphasis on lessons to be drawn from past historical experiences. In the present situation the historical consciousness allows for alternative guidelines for interpreting events taking place on national as well as on global arenas.
\end{abstract}

Keywords: modern China, Leninist capitalism, Confucian superstructure, guanxi, corruption, mianzi (face)

"Society is a human product. Society is an objective reality. Man is a social product.-----the institutional world requires legitimation, that is, ways by which it can be 'explained' and justified.” Peter Berger and Thomas Luckmann (1991: 79)

\section{Introduction}

A most fascinating problem in sociology concerns the dynamic interplay of cultural constructions of beliefs legitimating exercise of power and the social organization of production, distribution and consumption. A most striking difference in the impact of different ideologies legitimating politico-economic processes can be seen in the evolution of the Chinese and Indian civilizations from over the last 2500 years.

With the political unification of China under Qin dynasty (221 206 BC) the already existing idea of China as a cultural idea was further developed into a concept of China as a state having boundaries over which the Chinese emperor ruled through a formal system of administration rather than fluctuating personal relations to lower vassals. The ideology of the Chinese Empire "postulates a central government which is the ultimate political authority for the whole of a large territorial area delimited by frontiers. The administration of this empire is in the hands of office-holders, an Emperor with a staff of bureaucrats" (Leach, 1961: 54).

While the Chinese empire (like the Roman empire) was defined with reference to the borders of which the ruler exercised control, the Indian (and south-east Asian states) were defined with reference to ruling power centers and based on a very different legitimating ideology. According to Leach in the Indian states "the ideal ruler is not an office-holder, the Emperor, but an individual, Asoka; the pattern is one of charismatic leadership rather than bureaucratic continuity" (Leach, 1961:55). Exercise of charismatic leadership was based on Hindu or Buddhist cults, and the rulers exercised power on the model of the Chakravartin - the world conqueror who keeps the wheels of the chariot running spreading his dominion over the world as far as his power enable him to do. The Indian kingdoms did "not consist in a neat set of hierarchically organized sovereign states, sharply demarcated from one another and engaged in "foreign relations" across well-drawn frontiers. Still less did it consist in an overall domination by a "singlecentered apparatus state" under an absolute despot, "hydraulic" or otherwise. What it consisted in was an extended field of highly dissimilar political ties, thickening into nodes of varying size and solidity at strategic points on the landscape and thinning out again to connect --- virtually everything with everything else” (Geertz 1973: 336). Compared to the Chinese empire they were all relatively short-lived. Despite the long-term stability and uniformity of Chinese civilization there are however a range of 
contrasting views on central socio-cultural themes in this civilization - contrasts that it is important to keep in mind in order to have some understanding of 'the game Chinese play'. I shall here discuss some of these contrasting views.

\section{Collective Historical Consciousness}

In China there is a deep-rooted collective consciousness about the importance of Chinese history for understanding the present situation and for deriving guidance for action in this situation. This historical consciousness reflects a dominant cultural orientation, namely the centrality of the political order in Imperial China. "This highly general shared orientation by no means precluded the emergence of highly diverse and even confliction modes of thought concerning the interpretation of the orientation itself. --- Indeed this dominant orientation did not even prevent the emergence of tendencies of thought which minimized or even negated the role ascribed to the political order.” (Schwartz, 115). The historical long-term oscillations between centralization and decentralization of power, between isolation and international engagement, between ideas grounded in Chinese cultural traditions versus ideas of foreign origin. The historical consciousness thus constituted a discursive universe of contrasting views on critical issues that China confronted at various times.

The Chinese Agrarian State was one of seven primary civilizations (Inca, Maya, Aztec, Egypt, Mesopotamia and Indus being the others) that evolved from their own original agricultural beginnings. Among these primary civilizations, China is the only one that has survived into the twentieth century from its early beginnings with the Shang civilization (ca 1800 BC - ca 1100 BC) known for its magnificent bronze works, use of cowry currency, and invention of a primitive script (Chang, 1980: 230 - 243).

A most important event in this history was the establishment of the Chinese Empire 221 BC. In order for Europeans to imagine the significance of the history of this civilization we have to try to think what Europe would have been like if the Roman Empire instead of being fragmented into many small competing states towards the end of the fifth century AD had continued its socio- cultural development, and maintained its centralized political system and legal structure up until the last century.

With the fall of the Qing (Manchu) dynasty (1644-1912 AD) the Chinese empire had for more than 2000 (although for shorter periods internally fragmented) years been the greatest state on earth, a position that was based on internal development of its own traditions: a written language, nearly total centralization of political power, development of a complex bureaucracy that maintained the continuity of the empire while the dynasties changed, creation of rich cultural achievements in philosophy, literature and art, construction of vast physical infra-structures like the Grand Canal (more than $1700 \mathrm{~km}$ ) facilitating transport of grain from the rich agricultural areas in the south to the political centre in Beijing, the enormous system of great walls (about $6400 \mathrm{~km}$ ) protecting the realm against the nomadic groups on the steppes, important technological innovations like printing and gunpowder, and development of an advanced maritime technology that in the fifteenth century brought a Chinese armada to the coast of East Africa and possibly to other far a way places along the Pacific rim. Despite the long-term stability of the Chinese civilization one may discern important cultural contradictions within the historical consciousness.

\section{1 'Is China a society oriented towards the example of past glory' or 'Is China a society oriented towards innovations for future glory'}

For Europeans it is important to keep in mind that the idea about the Chinese state continued to define the whole society and peoples' idea of the right social order even in periods of fragmentation. This order was fundamentally based on the moral ideas of Confucius' teachings. They have had an enormous impact on how Chinese perceive themselves as individuals in society, and on how they perceive the State.

From the time of the Zhou Empire (ca 1100 BC), Chinese philosophical interests had centered on the issue of ethical prerequisites for political central dominance. This ethic sought to establish a kind of micro-macro congruence between the domain of 


\section{Dhaulagiri Journal of Sociology and Anthropology Vol. 4, 2010 | 5}

the family and the domain of the ruler. This was formulated in the doctrine of "the five relationships" of father-son, husband-wife, elder brother-younger brother, monarch-subject, and friend-friend. This doctrine held that if these relations were properly ordered in each individual's morality and behavior the whole society would be properly ordered.

Filial piety was the highest virtue and was the ideological foundation of patriarchal family system. This authoritarian family system "--was applied to the whole of society, providing a basis for authority and social order in political as well as in domestic life. The role of the emperor and his officials was merely that of the father writ large" (Reichauer \& Fairbank, 1960:30). Loyalty, filial piety, chastity, and righteousness were promoted as the most important moral characteristics for human beings. As a result of glorification of filial piety and loyalty, the mere position of a ruler or parent guarantied his privilege to receive respect and service from his subject or son.

Confucius lived between 551 and 479 BC during the last phase of the Zhou civilization (1100 - 221 BC. However during Confucius time the glorious Zhou civilization had from about 770 fallen into decline with brutal wars between feudal states.

A central theme in Confucius thought is to confront his contemporary troubled world with the ideal of good governance practiced in the first glorious phase of Zhou civilization. He argued that it was by studying the ancient rulers that one should seek guidance for action in the present.

This orientation was woven into beliefs and rituals indoctrinating a compelling belief in moral obligations defining hierarchical relations between people in a variety of contexts from family life to state matters. Confucius expresses this micro - macro congruence as follows: "The ancients who wished to illustrate illustrious virtue throughout the kingdom, first ordered well their own states. Wishing to order their states, they first regulated their families. Wishing to regulate their families, they first cultivated their persons. Wishing to cultivate their persons, they first rectified their hearts. Wishing to rectify their hearts, they first sought to be

\section{6 | Gunnar Haaland}

sincere in their thoughts. Wishing to be sincere in their thoughts, they first extended to the utmost their knowledge. Such extension of knowledge lay in the investigation of things" (Confucius, 2007). There was thus a continuum in religious practice and ethical beliefs from the individual level to the level of the emperor.

In the Chinese philosophical tradition there is however a rival to the Confucian school namely the so-called legalist tradition. The philosopher Han Feizi argued that in the state of a wise ruler, there is no need for literature or books, the law is the only creed. We don't need the sayings of appointed kings as our guides. His advice is to discount the past, emphasize the present and adapt to change. Shi Huangdi, king of one of the warring states, the Qin, took up these ideas. It was he who conquered the other warring states and established the first dynasty (Qin from 221- 206 BC) of the Chinese Empire.

Shi Huangdi's achievements include standardization of the written Chinese language; building canals; expanding the Great wall; and construction of a vast life-sized army of clay soldiers in an underground chamber near his tomb in Xian.

In addition to his many great contributions he is also known for his policy of deporting merchants, vagabonds and other useless people to populate the distant and barbaric region towards Vietnam, as well as for his destruction of historical records of the past in order to establish a permanent barrier between the past and the present (Burning the books and burying the scholars).

With the fall of the Qin dynasty in 206 BC, and establishment of a dynasty from the rivaling Han state, the legalist school gradually lost ground and Confucianism became the dominant state ideology right up until the revolution in 1911. It was the Han dynasties that developed the characteristic Chinese education based bureaucracy being in charge of collecting taxes, organizing corvée labor and suppressing secret societies that through Chinese history have constituted a constant threat to the central government. The period of the two Han Dynasties was a flourishing period in culture (e.g. historical chronicles, poetry, astronomy), in technological innovations (e.g. paper, porcelain, steel production), in trade (e.g. 
the silk road). The contribution of the Han dynasties were so important that today the term Han refers to China's majority population (92\%) sharing basic premises of Chinese culture in contrast to China's many minority groups (e.g. Mongols, Tais, Tibetans, Uyghurs, Yi). The example of the Shi Huangdi, the First Unifier of China and the legalist tradition became important again with Mao who ended the civil war and radically changed China's political system and ideology. In a conversation with the Egyptian Ambassador Mao said: "The first Emperor was the most famous emperor of China. In China there are always two opposite viewpoints. Some people support the First emperor, others oppose him. I myself endorse him, but I am against Confucius” (Yen Mah, 2003: 68).

At the Communist Party's Central Committee meeting in May 1958 Mao made a speech in which he personally praised the first emperor for being an authority on emphasizing the present while discounting the past and praised his policy of "Burning books and burying scholars”.

In pre-revolutionary time it was the same ethic that regulated behavior in public and non-public sectors of behavior, which meant that an important basis for administration of public affairs was based on a largely shared ethic and worldview among administrators and the rural and urban populations, while administration in post-revolutionary times in the absence of shared cultural framework to a larger extent had to be based on naked force. "Hegemony in modern China received no commonly accepted legitimization through culture; rather, it was represented by the culture of the barracks, a culture of compliance, slogans, posters, and mobilizations conveying messages and commands rather than meaning. This form of flat, cultureless culture was most emphasized during various movements or campaigns (yundong) that were especially characteristic of the first decades of the Communist era and perhaps achieved its strongest expression during the Great Leap Forwards of 1958 - 61, in the form of the mess halls that were meant to eliminate family commensalisms" (Cohen, 2005:56).

\subsection{Unity and Fragmentation in Chinese history}

In Confucian ideology the emperor had got his mandate from Heaven. The ruler should rule for the welfare of the people, if he abused his power the mandate from heaven would be withdrawn and given to someone else. The implication of this is that any man could claim he had been given the mandate from heaven. In times of crises, there often arose people who claimed such mandate and tried to convince people by magical tricks and deceits. In the middle of $19^{\text {th }}$ century a failed imperial scholar Hong Xiuquan inspired by missionary teachings proclaimed himself a younger brother of Jesus and started the Taiping revolt to fight corruption and improve the conditions of the farmers, threatening both the empire and the interests of foreign merchants. With the help of foreign mercenaries Hong was defeated. Another challenge from below was the Boxer Rebellion in 1900. "The Fist of Harmony Society", one of the many secret societies at that time, believed their martial arts exercises made them invincible to bullets. Believing that foreigners like missionaries and merchants were destroying China, they set out to overthrow the Imperial government and expel the foreigners. Again with the help of foreign powers the rebellion was crushed, and China forced to make further concessions. These events are part of collective historical consciousness in China and they go a long way to explain the Chinese Governments sensitivity to organized challenges from below. Recently a granary clerk, Li Hongzhi has created a new spiritual movement, Falun Gong. This is just the latest one in a long historical sequence of such tricksters. To understand the government's harsh crackdown on the movement one should see it in light of a long historical tradition of autocracy, rather than in the light of the present communist one-party State as western media tend to do. Like previous movements Falun Gong combines martial arts with mysticism. What triggered the government's crackdown was its ability to mobilize people quickly as shown in the peaceful demonstration 25 April 1999 protesting the government's treatment of its practitioners in Tianjin. An underlying concern in the government's reaction is probably that such millenarian movements tend to thrive on and encourage discontent produced by social tensions, e.g. rural-urban inequalities, or cultural tensions as those expressed by Li Qihua 
(former head of the top military hospital that serves the leadership) when he said "that Marxism-Leninism could explain many things about the natural world but that there were many things beyond the natural world that it could not explain. The teachings of the Falun Gong filled that void and should not be seen as incompatible with Marxism-Leninism could fill that void (Fewsmith, 2000: 42-43).

\subsection{Should Chinese History be Seen as a History of Glory or as a History of Humiliation}

On the one hand the Chinese feel pride in their civilization and its important accomplishments. On the other hand they feel inferiority in the face of the technological superiority of the west today, combined with a couple of hundred years of humiliation at the hands of western powers. Both the pride and the humiliations have implications for the Chinese perception of foreigners.

During Han (first Han 206 BC - 9 AD and second Han 25 Ad 220 AD) and Tang (618 - 907) dynasties, the old Confucian myth of a highly civilized China surrounded by admiring barbarians gave the Chinese sense of superiority, which they felt was due to their possession of superior virtue. The Mongol occupation of China under Khubilai Khan and the establishment of the Yüan dynasty (1271 - 1368) was a traumatic experience, because it proved that the sheer fighting ability of the Mongols could overcome the Will of Heaven. It showed that virtue could not survive unless supported by strong military power. The shortness of the foreign domination did however also show that power alone could not survive in China for long without the Confucian virtues. Maintenance of the basic content of Chinese civilization thus required both cultivation of Confucian virtues and organization of strong military forces.

In the nineteenth century China was again threatened by foreign domination, particularly British imperialism. Western imperialism dramatically undermined the Chinese empire and its legitimating Confucian ideology through demands for extraterritorial rights, especially during the outrageous opium wars (1839-42). The background was increased western demand for Chinese products like tea, silk, porcelain, while there was hardly any Chinese demand for western products. This trade imbalance led to an inflow of silver to China. The western response to this trade imbalance was through third party trade, exchanging their products with Indian goods that had a market in China. These goods were cotton and opium. The Chinese government had in 1839 established drastic laws against opium trade, and in connection with this, they detained the entire foreign community in Guangzhou and destroyed a large amount of illicit British opium. In the war that followed China was disastrously defeated and had to sign the first unequal treaty ceding Hong Kong to the British and allowing establishment of so-called concessions settlements in several Chinese ports, allowing among other things the British to freely import opium from India for sale in China. At the same time Christian missionaries were allowed to expand their activities in China, and an increased number of Chinese students went abroad for higher studies. All his together with other political events like the Taiping rebellion (1851-64 against the Chinese emperor) that was defeated with western help including Charles Gordon who was promoted to one of the highest ranks in the weak Chinese army. This dependence on foreign intervention further weakened the legitimacy of the Qing government at the same time as foreign powers took over peripheral states that previously had acknowledged Chinese suzerainty and given tribute to the emperor - France in South east Asia, Britain in Burma and Kowlon, Russia in Xinjiang, Japan in Taiwan. These humiliations stimulated a reform movement from the imperial court in 1898, but this lead to intense resistance from the conservative ruling elite particularly the Manchus. This was the background to the Boxer movements (1900) that spread over northern China leading to burning of missionary stations and killing of Chinese Christians, and eventually attacking foreign concessions in Beijing. An allied relief expedition crushed the Boxers as well as the Qing government forces that had declared War on the foreign invaders. The defeat allied victory lead to, increased Russian influence in Manchuria (an influence it lost to Japan after Russo - Japanese war 1904-1905) and increased British influence in Tibet, although the 1906 AngloChinese Convention reaffirmed China's legitimate authority over its dependency Tibet. However, it is easy to understand that the Chinese suspected that this was a foreign attempt to interfere in a region within China's sphere of influence. 
Failure of reform and the Boxer up-rising convinced many Chinese that the only solution was revolution. Led by Sun Yat Sen this occurred in 1911 - the empire was demolished and a modern socialist inspired ideology was emphasized. However the chaos continued, and a functioning state was not re-established, local war lords ruled large parts of the country, and bloody wars were waged with Japan and between Guomintang and the communist. Finally Mao Zhe Dong in 1949 after almost 40 years of war-lordism succeeded in establishing order like the first Qin emperor Shi Huangdi after 500 years of feudal warfare established orderly rule in China more than 2000 years earlier.

Mao's State was built on a very different foundation from the traditional Confucian ideology of empire. It was largely constructed on the western ideas of Marxism, socialism, one party state, industrialization and military power. An element in Mao's strategy of undermining the Confucian ideology that legitimized the old regime was to destroy the patriarchal family that was so important in reproducing Confucian ethics.

\section{Marxist Theory, Confucian Morality and Material} Consumerism as Factors in Modernization

However, while Mao's break with the past was an important factor giving new directions to socio-cultural development, this development was dramatically accelerated with Deng Xiao Ping's economic reforms from the late 1970s. This was apparently inspired by success of the four little Dragons: Taiwan, Hong Kong, Singapore and South Korea, three of which were predominantly Han Chinese falling within the China centered Confucian culture of East Asia. Maybe Deng also remembered that Marx had said that capitalism was the most efficient way of developing the forces of production, and that attempts to skip the capitalist phase and go directly from feudalism to socialism would lead to the Asiatic mode of production characterized as Oriental despotism.

According to Marxist dogma it seems rather strange that today the infrastructure of society is largely based on a capitalist mode of production (Leninist capitalism) that is regulated by a government dominated by the Communist Party of China, and which to a large extent draws its legitimizing support from an ideological superstructure inspired by Confucian harmony thinking rather than Marxist class struggle thinking.

Back to the Dragon metaphor, Dragon evokes China 'the Mighty Dragon' that symbolizes the illustrious and military powerful China. Intellectuals and politicians tried to uncover the secret of what they regarded as the successful modernization of the four little dragons. The post-Tianaman regime has increasingly emphasized Confucianism as the source for "the Mighty Dragon” nationalist appeal to legitimacy. Samuel Huntington has described the Chinese governments embracement of Confucianism as follows: "In the early twentieth century Chinese intellectuals, independently paralleling Weber, identified Confucianism as the source of Chinese backwardness. In the late twentieth century, Chinese political leaders, paralleling Western social scientists, celebrate Confucianism as the source of Chinese progress. In the 1980s the Chinese government began to promote interest in Confucianism, with party leaders declaring it "the mainstream" of Chinese culture. Confucianism also, of course, became an enthusiasm of Lee Kuan Yew, who saw it as a source of Singapore's success and became a missionary of Confucian values to the rest of the world” (Huntingon, 2002: 106). This nationalism included an element that Mao strongly rejected, namely commercialism. This commercialism has far-reaching consequences for consumption patterns and child rearing. The multinational corporations provide a main mechanism mediating this link.

An important element in global international corporations' strategy is to go glocal, i.e. participate in local affairs, e.g. by sponsoring school event to align their products to the local context of childhood - international products shedding foreign characteristics and merging with the local culture of consumption. The multinational corporations thus play an important role in the Cultural transformation of Mainland China in the sense that their products are marketed not only as commodities but also as cultural goods - the culture of modernity. In other words, rather than seeing interaction with the west as a one-way process of westernization, we are faced with a complex interaction of local and global 
processes leading to social and cultural 'hybridity' that has been labeled ‘glocalization’ (Robertson, 1992)

China's modern one child policy combined with Deng's commercialization has had far-reaching effects on the family level; further undermining the Confucian based patriarchal ideology. In the traditional family structure children were brought up to respect the elders and to orient their attention to the parents' example. Today, this has changed, now it is the parents who orient their attention to the wishes of the new little emperors/empresses - the children. Their wishes increasingly determine parents' allocation of time and resources. Now the values children internalize are to a less extent the values of the parents. Instead through children peer group pressures, it is the values communicated in TV series and advertisements that influence their thoughts. However recently there are reports that the Chinese Government seeks to reinforce respect for the elderly by allowing parents to sue children who do not honor their traditional obligations to care for them in old age.

Instead of finding a China rooted in traditional culture, my impression is that if we look beyond the cultural surface of language and social etiquette, people in China today are motivated by concerns very similar to what we can recognize in Europe. Today the country is participating in a global youth culture. This culture is ego centered, orienting people's concerns towards selfrealization in individual achievements as manifested in success in the consumer society, not only by expressions of self-identity in search for the most recent fashions, but also in selection of marriage partner based on individual romantic love (Farrer, 2002). When I go to supermarkets or discuss with Chinese friends - it is consumption of modernity that is the dominating concern - going to McDonald can certainly not be a matter of consuming good food, it is more a matter of being shown to be modern, to associate with a modern style of life (Watson, 1997).

This new global culture emerging in China is manifested in import of American style celebrations: Mother's day, father's day, Halloween, birth day parties with candles, cakes and gifts. Even weddings are increasingly taking on a western flavor where the bride is dressed in a white bridal gown - white traditionally being inauspicious, associated with mourning and funerals in China. The culture of modernity is shown in widely shared belief in progress, particularly in its technological dimensions.

However like in the west, secularity leads many to search for something that gives meaning to life beyond acquisition of material objects, and which satisfy individuals' emotional needs for belonging to larger units of solidarity. It is on this background I think we have to understand the growth of religious movements like Buddhism, Taoism, Christianity, ancestor worship and the esoteric Falun Gong. (Ovrmeyer, 2003; Ashiwa and Wank, 2009; Mayfair Mei-Hui Yang, 2008)

\section{Is Guanxi: 'a matter of moral obligations' or 'a matter of Instrumental Manipulation Similar to Corruption (fubai)"}

Guanxi should be seen both in the light of Confucian based moral obligations and in the context instrumental profit seeking considerations. (Huang, 2007). Guanxi refers to personal networks of social relations. One's life chances in society are to a large extent related to the scale and the power of the quanxi relations one can mobilize. Such relations are primarily ascribed by birth and involve obligations to exchange gifts, to cooperate in economic activities and to support each other in politico-administrative activities. The relations making up guanxi networks may however also be actively created, typically by an initial gift leading to endless process of gift exchanges, including banquets, family ceremonies, administrative favors etc. (Yan, 1996; Kipnis, 1997; Mayfair Mei.Hui Yang, 1994)

The obligations in guanxi relations are based on Confucian ethical values called renqing referring to understanding others' emotional situation, and to moral norms for how on the basis of such understanding to respond to them (morality of empathy). The morality of renqing does not only constitute the basis for smallscale guanxi networks of family and neighbourhood, people also appeal to it when they expand their quanxi to networks of much larger scale. Behaving according to the morality of renqing is also recognised in such extended quanxi relations. The problem is that 
people may appeal to the morality of renqing in order to use guanxi relations for private instrumental purposes. This may create a problem in the sense that people in bureaucracy and business enterprises feel compelled to honor moral obligations that contradict the legal rules for proper behavior in these organizations, or even worse be tempted to gain private individual benefits by giving benefits to those who offer attractive gifts. It is when this occurs that we enter into the muddy waters between guanxi morality and corruption (fubai).

The opening up for expansion of a capitalist economy in a state where large bureaucracy plays an important role in controlling conditions under which capitalist enterprises operate, create another set of tensions. In this enormous and complex country performance in administrative office according to 'ideal' bureaucratic rules and regulations will necessarily be time consuming, often leading to 'red-tape' delays. To overcome this it is therefore an obvious advantage if business firms can find a backdoor to the incumbents of bureaucratic offices. (Luo, 2007)

To get the wheels running they need to be greased, you need connections (guanxi) that can bring you through the backdoor to the real decision-makers - you need to know somebody and that somebody must feel s/he has an obligation to connect you to those who decide.

The opening up involves a dramatic change with unforeseen consequences with many possible pitfalls. A most dramatic change has been the transfer of state-owned enterprises (SOE) to private ownership. According to official statistics, state-owned economy accounts for 35\% GDP most importantly contributed by industries such as telecom, banking, petroleum, electricity which are all controlled by the government. The real estate economy, which is a major GDP pusher, is also largely a government-run-business.

This government percentage is however heavily undervalued, because companies with shares controlled by the government are not regarded as state-owned economy. One of the most problematic consequences of the transfer is what one of the participants in the Chinese debate, He Qinglian calls "marketization of power" (He 2002). The growth of private economic capital has according to her

\section{6 | Gunnar Haaland}

been closely connected to accumulation of political capital in the sense that bureaucrats play an essential role in allocation of licenses and contracts and that economic entrepreneurs try to influence favorable decisions through bribes.

Today companies - local and foreign - spend heavily on establishing and maintaining guanxi relations to those who wield influence. To play the guanxi game without being accused of corruption has become a fine art. If one does not play it well one risk loosing out on a good deal, if one plays it poorly one risk not only losing out on a deal, but also being accused of corruption (Smart, 1993).

The risks involved in playing it were clearly outlined in a speech by Deng at the third plenary session of the central advisory committee of the communist party of China, October 22 1984:

"Some governmental functionaries have committed economic crimes so serious that they caused the state financial losses amounting to as much as several million, or even ten million Yuan. Why can't they be sentenced to death in accordance with the criminal law” (Ikels, 1996:39)?

\section{Face (mianzi) as an individual matter and as a collective matter.}

A concept related to guanxi is mianzi (face). Face has both an external aspect (the observable face we see), and an internal aspect (my feelings, thoughts and self respect). These two aspects are closely related in the sense that the face we see is believed to mirror our inner selfhood. An important virtue emphasized in Confucian morality is that the inner selfhood should be in harmony. The physical face with its different features like the eyes (where others look to detect whether we are lying or not), the mouth (through which we may tell lies or truths), and other facial features (which may express anger, ridicule, love, pleasure etc) may indicate the state of our inner harmony. Consequently it is important to maintain a facial composure that does not indicate inner disharmony. Since inner harmony is a precondition for group harmony, people are concerned about not disturbing the inner harmony (mianzi) of individuals they are related to in networks or 


\section{Dhaulagiri Journal of Sociology and Anthropology Vol. 4, $2010 \quad 17$}

groups. This concern expresses the regard in which people hold each other, including self-respect and dignity as well as the prestige one enjoys in the community.

Face may become important in business dealings because officials may try to avoid making decisions for which they can be held responsible if things go wrong. This leads to diffuse systems of decision-making where it is difficult to place the blame squarely on any person. This combined with a Chinese tendency to view business interaction as a 'zero-sum game' often leads to rather time-consuming negotiations. The trick is to construct a deal that both partners can see as "win-win game”. An important dilemma in China is to how to adapt to a still western dominated global economy (this is now changing rapidly), while maintaining a distinct Chinese identity

Face is by no means only an individual asset. Organizations have face too, so have countries. In a secular China I expect that a patriotic nationalism will be of increasing ideological importance affecting the way Chinese individuals and agencies interact with foreign agents.

\section{Conclusion}

An underlying assumption in this article is that the human construction of society is not reducible to processes taking place in an assumed determining economic infrastructure. Infrastructural processes set limits to what society humans can construct, but what society is constructed within these limits is shaped by processes on several interdependent levels from political mobilization of power to symbolic construction of legitimacy of the social institutions regulating access to valued goals. Processes on the different levels are interdependent but not reducible to each other. I have tried to explore how the interplay of processes on different levels is manifested in the tension between some contrasting views on important themes in Chinese civilization.

I am far from certain about the stability of the government and how it manages to cope with new tensions not the least those that are caused by the increasing income gap created by the way guanxi

\section{8 | Gunnar Haaland}

practices lead to Capitalization of Power, particularly if new independent entrepreneurs are drawn into guanxi relations to party members, solidifying the Communist Party - Commercial complex", and complementing the existing "Communist Party Educational complex". On the one hand these complexes serve to reduce potential conflicts between interests of bureaucrats and entrepreneurs, but on the other hand it creates a gap between the winners and losers in the guanxi game.

I think it is important to have an idea of these tensions in order in order to have some understanding of China's reactions to events taking place in its dealings with the Western world.

In the fifteenth century the leader of the mightiest power on earth, the Ming emperor decided that the barbaric world outside China was worthless of contact because that world had nothing to offer the civilized China. This had catastrophic consequences and isolated China from technological and economic developments taking place on the global arenas, leading to the humiliations of the nineteenth and twenties centuries. Today China is participating actively on the global arena engaging the rest of the world culturally, politically and economically, not the least in development assistance in ways that certainly compare favorably with western aid projects.

Tension between past glory and past humiliations is clearly present today in contrasting viewpoints in the Chinese culturally constructed historical consciousness. This I think can be seen in the contrast between admiration for western cultural products from popular music to scientific innovations, and perception of the West lead by USA as a major rival on the global scale. Given the Chinese perceptions of face (mianzi) as extending to collective units, I expect China to become increasingly sensitive to foreigners showing respect to the face of China. It is in this light we should understand the Chinese government's reaction to the Nobel Peace Prize for 2010 awarded to the jailed Chinese dissident Liu Xiaobo. 


\section{References}

Ashiwara, Yoshiko and Wank, David (eds) (2009). Making Religion, making the State. Stanford: Standford University Press.

Berger, Peter \& Thomas Luckmann (1991). The Social Construction of Reality. London: Penguine Books

Chang, Kwang-Chih (1980). Shang Civilization. New Haven: Yale University Press.

Cohen,Myron.2005). Kinship, Contract, Community, and State. Standford: Standford University Press.

Confucius (2007). The Great Learning. www.forgottenbooks.org

Farrer, James (2002). OPENING UP. Youth Sex Culture and

Market Reform in Shanghai. Chicago: Chicago University Press.

Fewsmith, Joseph (2000). Historical Echoes and Chinese politics: Can China Leave the Twentieth Century China Behind China Briefing 2000. The continuing transformation (ed: Tyrene White). London: An East Gate Book. M.E Sharpe.

Geertz, Clifford (1973). The Interpretation of Cultures. London: Fontana Press.

He Qinglian (2002). The Pitfalls of Modernization. Soshisha,

Huang, Jiansheng (2007.) Moral Debts the cannot be repaid. Unpublished Ph.D. Thesis. Department of Social Anthropology, University of Bergen

University of Bergen.

Huntington, Samuel (2002). The Clash of Civilizations. London: The Free Press.

Ikels, Charlotte (1996). The Return of the God of Wealth. Standford: Stanford University Press.

Kipnis, Andrew (1997). Producing Guanxi. Sentiment, Self and Subculture in a North China Village. London: Duke University Press.

Leach, Edmund (1961). The Frontiers of Burma. Comparative Studies in Society and History. Vol III (1), 49-68

Luo, Yadong (2007). Guanxi and Business. Singapore: World Scientific Publishing Co. Pte. Ltd

Mayfair Mei-Hui Yang (1994). Gifts, Favours \&Banquets. The Art of Social relationships in China. Ithaca: Cornell University press.
$20 \mid$ Gunnar Haaland

Maifair Mei-Hui Yang (ed) (2008). Chinese Religiosities, Afflictions of Modernity and State Formation. Los

Angeles: University of California Press. Overmeyer,

Daniel (ed) (2003). Religion in China Today. Cambridge: Cambridge University Press.

Reichauer, Edwin \& Fairbank, John (1960). East Asia. The Great Tradition. London: Allen and Unwin LTD:

Robertson, Roland (1992). Globalization. London: Sage Publications.

Schwartz, Benjamin (1996). China and Other Matters. London: Harvard University Press.

Smart, Alan (1993). Gifts, Bribes, and Guanxi: A Reconsideration of Bourdieu's Social Capital. Cultural Anthropology, Vol. 8, No. 3: 388-408.

Watson, James (ed) (1997). Golden Arches East, McDonald's in East Asia. Stanford: Standford University Press.

Yan, Yunxiang (1996). The Flow of Gifts. Reciprocity and Social networks in a Chinese Village. Standford: Stanford University Press.

Yen Mah, Adeline (2003). A Thousand Pieces of Gold. London: Harper Collins Publishers. 